\title{
A Review of the Linkage between Supervisory Support and Training Transfer
}

\author{
Gan Jen Ling, Halimah M. Yusof*
}

Department of Human Resource Development, University Teknologi Malaysia, 81310 UTM Johor Bahru, Johor, Malaysia

*Corresponding author: halimahmy@utm.my

\begin{abstract}
This article reviewed past studies that were carried out in the past decades (2002-2015) on the linkage between supervisory support and training transfer. Most of the organizations have invested billions of dollars onto training. However, training transfer is still in unsatisfactory status. Supervisory support is recognized as one of the aspect that could have an effect on training transfer. However, the importance of supervisory support in training transfer has been overlooked in the past studies. Thus, this paper intends to highlight the needs to make further investigations on the linkage between these two variables. Some suggestions were provided for future studies.
\end{abstract}

Keywords: Supervisory support; training transfer; transfer research

(C) 2017 Penerbit UTM Press. All rights reserved

\subsection{INTRODUCTION}

Training and Development (TD) has been paying attention to develop employees in the aspect of knowledge, skill, and attitude (KSA) in these recent years (Werner and DeSimone, 2011). Many organizations have planned their effort in offering support on employees' learning (Noe, 2013). It is argued that, organization's effort is essential to improve employees' KSA because employees can perform better with improved competency (Werner and DeSimone, 2011). From this, it can be seen that, TD is a vital department in making employees to be equipped with competencies. Since the investment onto TD is huge, training transfer is concerned by the organizations after every training program has been conducted. Training transfer becomes the main concern because it will be able to help organizations and employees to reach their goals effectively.

Training transfer refers to the ability of participants to apply learned knowledge and skills from training classroom to their workplace (Yamnill and McLean, 2001). Training transfer can help an organization and employees to accomplish goals with effective routines (Bhatti and Kaur, 2010). It becomes a concern to researchers and Human Resource Development (HRD) practitioners when training transfer is recognized as major issue in HRD field in recent years. Thus, they have been trying to put effort in resolving this issue. However, it is criticized that, HRD practitioners have been wasting a lot of money to do trial and error method in making training transfer succeed (Jehanzeb and Bashir, 2013). As an evidence, Hussain (2011) reported that many organizations had been investing billions of dollars but the training transfer is still in unsatisfactory status. Burke and Hutchins (2007) revealed that, up to 70 percent of the employees did not apply their learned skills and knowledge onto their job. From these statements, it can be seen that HRD practitioner in organizations have not solved the training transfer issue yet. Blume et al. (2010) claimed that, training transfer literature is lacking of empirical synthesis. HRD practitioners are still looking for good theories of training transfer which are developed by researchers (Grossman and Salas, 2011). Gil et al. (2016) argued that, the findings from training transfer research is important for those organizations' personnel because the findings can act as conceptual basis in an organization. This is because every good theory must had been tested empirically, thus providing beneficial advice to HRD practitioners. From these, it can be seen that theories in studies play essential role to practitioners, as well as future researchers.

There are many factors that can affect the training transfer. For instance, the model which focused on participants' characteristics (Wexley and Latham, 2002), has been expanded by including the factor of working environment because working environment explained more variance onto training transfer (Noe and Schmitt, 1986). The dimensions of working environment includes subordinates support, peer support, top management support, and supervisory support. However, working environment has been overlooked by researchers in past studies (Manju and Suresh, 2011). In addition, among the dimensions of working environment, it is revealed that there is a need to further investigation onto the linkage of supervisory support and training transfer (Grossman and Salas, 2011). Supervisory support is described as the extent to which manager gives support and makes training transfer as priority (Hua et al., 2011). This is due to the mixed findings obtained from the past studies. In which, some studies found that there is strong linkage between supervisory support and training transfer, but there are also studies found out there is weak or no linkage between the variables.

Although supervisory support is important in training transfer, it received limited attention from researchers (Hua et al., 2011; Ng, 2015). This is because most of the researchers focused only on the variables of trainees' characteristics and training design (Bhatti et al., 2010; and Tajudin et al., 2014). Many scholars had proved the positive linkage between trainees' characteristics and training transfer (Van der Locht et al., 2013; Wen and Lin, 2014; Awais Bhatti et al., 2014). While, training design had been proved that it has low and moderate linkage 
with training transfer (Kasim and Ali, 2011; Abdullah and Suring, 2011; Shi and Liu, 2015). Hence, future researchers need to put more attention on the impact of supervisory support towards training transfer to obtain more comprehensive understanding on this linkage. For instance, research of supervisory support in training transfer is lacking in Malaysia manufacturing industry, compared to other industries in Malaysia, such as service industry. This is because it is argued that different organizational context might have different effects of supervisory support towards training transfer (Velada and Caetano, 2007). Thus, there is a need to examine the generalizability of result in different organizational context. Thus, the aim of this paper is to review recent published articles on the linkage between the supervisory support and training transfer.

\subsection{LITERATURE REVIEW}

\section{Supervisory Support}

One of factors that can affect the effectiveness of training transfer is supervisory support. If supervisor is able to give ample support in working place, training transfer will be more effective to be carried out. Supervisory support is defined as the extent to which the supervisor behaves in the way that improves the process of applying knowledge and skills among workers after training programs (Nijman et al., 2006). In another word, supervisory support occurs when employees are being exerted positive actions by supervisors. On the other hand, when weak supervisory support is perceived by employees, employees will be failed to apply their skills and knowledge (Zumrah and Boyle, 2015). Thus, it can be seen that, the environment of working place especially supervisory support is a critical element in making training transfer to occur.

Supervisory support can be done in different methods. One of the ways to show supervisory support is assisting trainees to set goals for training transfer (Sari and Basri, 2015). One of the theories that can explain this kind of supervisory support is Goal Setting Theory. According to Goal Setting Theory, it is claimed that, employees can be directed by setting goals, because excellence can be reached through tough goals (Locke and Latham, 1990). Hence, it is concluded that, supervisor can show supervisory support by the approach of goal-setting and leading the employees to achieve successfulness (Ömer, 2016). Supervisor's participation is also considered as one of the factors that makes subordinates completing task in an efficient way, which is carrying out training transfer in workplace (Certo, 2015).

It is cautioned that, consistency in providing supervisory support to employees should be paid attention by supervisors or management (Bhatti et al., 2013). This is due to it was discovered that, subordinates will be feeling lost when supervisors are not providing supervision to lead them (Bhatti et al., 2013). Hence, it can be concluded that, training transfer effectiveness will be decreased if the level of supervisory support is lacking.

In more specific description, supervisory support has been characterized into few terms. It is argued that, supervisor can support trainees in several ways, there are emotional support, instrumental support, and giving feedback to trainees after the trainings (Kossek et al., 2011). This statement is supported by another scholar because feedback is viewed as critical element in communicating necessary improvement, inspiration to join training, and providing assistance in applying skills and knowledge (Van der Klink et al., 2001).

\section{Training Transfer}

In current years, training transfer has been the core issue in Human Resource Development (HRD) field, thus HRD professionals and researchers have been exerting effort in training transfer for the purpose to resolve this problem in HRD field. It is argued that training transfer is the approach which assists the organization and employees to reach their objectives with more effective practices (Bhatti and Kaur, 2010). The process of training transfer is also defined as the flow of applying trained skills and knowledge on the job at workplace (Burke and Hutchins, 2007).

In later time, it is argued that, throughout the process of training transfer, besides applying new skills and knowledge at workplace, trainees are also expected to apply their new behavior and attitudes onto their job after the training programs (Velada and Caetano, 2007). In addition to that, employees are also needed to generalize learned materials to the context of real-world working place during training transfer process (Abdullah and Suring, 2010). Besides, determination is also needed among employees in order to improve job performance at workplace (Grossman and Salas, 2011). Hence, the training transfer is considered as essential for training programs to be efficient and effective (Nijman et al., 2006). Besides, the return on investment (ROI) of conducted training will only be achieved when trainees have successfully applied learned material (Nijman et al., 2006).

The well-known and foundational framework consists of three factors that are able to influence training transfer (Baldwin and Ford, 1988): (a) characteristics of trainee such capabilities or skills, factor of personality, and motivations; (b) environment of working place such as manager's or colleagues' support, obstacles or opportunities to apply knowledge; and (c) training design factor such as principles of learning, learning retention, content of training, and training sequencing. All these factors are able to affect the process of training transfer. For instance, if workers are not supported by manager or immediate superior, it may be impossible that training transfer will occur in the organization.

\section{The Relationship between Supervisory Support and Training Transfer}

Some researchers have been studying the effects of participants' characteristics and training design, however, supervisory support has been overlooked by past studies (Tajudin et al., 2014). This has drawn attention to training transfer research. One of the learning transfer system in Holton's training transfer model is supervisory support (Holton et al., 2000). Supervisory support is known to have an effect on the process of training transfer (Nijman and Gelissen, 2011). It was discovered by several studies that supervisory support has positive relationship to training transfer (Cromwell and Kolb, 2004; Velada and Caetano, 2007; Joo et al., 2011; Kia and Ismail, 2013; Zumrah, 2014). In other words, when the level of supervisory support increased, the level of training transfer will be increased too. From this, it can be seen that, management of organization should pay attention onto supervisory support if they want to increase the occurrence of training transfer. Supervisor plays important role to provide support such as giving feedback to trainees to improve the process of training transfer. 
Supervisor is the key element to make training transfer to occur effectively (Park and Wentling, 2007). In other words, if supervisor is not willing to provide support, training transfer will not happen effectively. However, there are still limited empirical studies that confirm the positive linkage between supervisory support and training transfer, although there are scholars who agreed on the positive linkage between these two variables (Van der Klink et al, 2001). It was discovered that there was some studies who found negative linkage between the supervisory support and training transfer (Fitzgerald and Kehrhahn, 2003). This is because it is believed that supervisory support has less influential in autonomous job setting, where more freedom is given to the subordinates (Fitzgerald and Kehrhahn, 2003). This can be seemed that job setting can affect the findings onto the linkage between the supervisory support and training transfer. From these results revealed by scholars, it can be concluded that empirical research still did not provide any consistent findings on the linkage between supervisory support and training transfer.

As reviewed from articles on the linkage between supervisory support and training transfer, besides job settings, findings could be different due to different dimensions on supervisory support variable. "Employee development" was used as the dimension of supervisory support (Chiaburu and Tekleab, 2005). This dimension of employee development has failed to prove the linkage between supervisory support and training transfer. Conversely, linkage between variables is found when the dimension of "discussion with supervisor to use new learning" has been used in the study (Lim and Johnson, 2002). From these studies, it can be claimed that, by using different dimensions or different operational definitions, it might affect the findings of the linkages.

Moreover, researchers should also be cautioned with the study context, such as country. It is argued that there is a gap in the literature, where no ample training transfer studies have been carried out in developing country (Zahari and Obaid, 2014). More empirical training transfer studies in developing country should be conducted to examine the linkage. This is because different countries might yield different findings on the linkage between supervisory support and training transfer. For instance, studies in Malaysia obtained a result which showed positive and significant relationship between supervisory support and training transfer (Kia and Ismail, 2013; Zumrah, 2014; Haslinda and Mahyuddin, 2009; Ismail et al., 2010). They mentioned that supervisory support has effect on training transfer. In another word, supervisory support can influence the occurrence of training transfer. If the learners are given encouragement in transferring knowledge, the respondents will be more likely to transfer learned materials. However, in contrast, it was discovered that supervisory support has no influence onto the training transfer in Myanmar private manufacturing companies (Maung and Chemsripong, 2014). It can be seen that the findings on linkage between these two variables are not consistent from years to years in different countries. From both contrast findings, it can be concluded that empirical past studies still were not able to provide clear idea of the linkage between the supervisory support and training transfer. It is argued that, these contradictory findings have made the linkage remains indefinite (Velada and Caetano, 2007).

Overall, the impact of supervisory support on training transfer is remained unclear in past studies. There are mixed findings on the link of supervisory support and training transfer. Specifically, this paper focuses on reviewing the empirical studies that were carried out to test the linkage between supervisory support and training transfer. It excludes those studies which used the samples of schools' students and those variables which are unrelated to this study. Major articles refer to those published in some major organizational behaviour journals, such as Personnel Psychology and European Journal of Training and Development.

\subsection{CONCLUSION}

As a conclusion, several empirical studies from the year of 2002 to the year of 2015 had been reviewed on the linkage between supervisory support and training transfer. It can be seen that, there are still inconsistent findings found among past studies. Some researchers found there is a linkage between supervisory support and training transfer, while some researchers found there is no linkage between the variables. This is because different contexts or different dimensions that being used by researchers might affect the result of study. Apart from that, there are some recommendations suggested for further research. It is cautioned that it is vital to recognise applicable concepts, theories, and research in training transfer literature (Nilsen, 2015). Besides, future researchers should utilize the advanced statistical tool which will help in building theory of training transfer that produces a constant way to examine training transfer (Reio et al., 2015). Moreover, variables can be tested in different contexts to obtain a more consistent finding on the linkage. On top of that, the study of training transfer increases the use of real job context. This indicates that future researchers should take sample of organizational personnel instead of students from colleges. It is argued that, data collected from students are significantly different from organizational personnel (Sekaran and Bougie, 2011).

\section{References}

Abdullah, D. N. M. A., \& Suring, J. C. (2011). The Relationship Between Motivation to Transfer, Training Design, Transfer Climate and Transfer Of Training. In International Conference on E-business, Management and Economics, Dubai, United Arab Emirates.

Awais Bhatti, M., Ali, S., Isa, M., Faizal, M., \& Mohamed Battour, M. (2014). Training Transfer and Transfer Motivation: The Influence of Individual, Environmental, Situational, Training Design, and Affective Reaction Factors. Performance Improvement Quarterly, 27(1), 51-82.

Baldwin, T.T. and Ford, J. (1988). Transfer of Training: A Review and Directions for Future Research. Personal Psychology, 41(1), 63-105.

Bhatti, M., \& Kaur, S. (2010). The Role of Individual and Training Design Factors on Training Transfer. Journal of European industrial training, 34(7), 656-672.

Bhatti, M., Mohamed Battour, M., Pandiyan Kaliani Sundram, V., \& Aini Othman, A. (2013). Transfer of Training: Does It Truly Happen? An Examination of Support, Instrumentality, Retention and Learner Readiness on the Transfer Motivation and Transfer of Training. European Journal of Training and Development, 37(3), 273-297.

Blume, B. D., Ford, J. K., Baldwin, T. T., \& Huang, J. L. (2010). Transfer of Training: A Meta-Analytic Review. Journal of Management, $36(4), 1065-1105$.

Burke, L. A., \& Hutchins, H. M. (2007). Training Transfer: An Integrative Literature Review. Human Resource Development Review, 6(3), 263-296.

Certo, S. (2015). Supervision: Concepts and Skill-Building. McGraw-Hill Higher Education.

Chiaburu, D. S., \& Tekleab, A. G. (2005). Individual and Contextual Influences on Multiple Dimensions of Training Effectiveness. Journal of European Industrial Training, 29(8), 604-626.

Cromwell, S. E. \& Kolb, J. A. (2004). An Examination of Work-Environment Support Factors Affecting Transfer of Supervisory Skills Training to the Workplace. Human Resource Development Quarterly, 15(4), 449-471.

Fitzgerald, C. G. and Kehrhahn, M. T. (2003) 'Transfer of Training in an Autonomous Job Context', Storrs, CT: University of Connecticut.

Gil, A. J., Molina, J. A., \& Ortega, R. (2016). Determinants of Training Transfer in the Wine Industry: Conceptual Hypotheses and Results for Rioja (Spain). Journal of Wine Research, 27(1), 65-83.

Grossman, R., \& Salas, E. (2011). The Transfer of Training: What Really Matters? International Journal of Training and Development, 15(2), 103-120. 
Haslinda, A., \& Mahyuddin, M. Y. (2009). The Effectiveness of Training in the Public Service. American Journal of Scientific Research, 6(1), 39-51.

Holton III, E. F., Bates, R. A., \& Ruona, W. E. (2000). Development of a Generalized Learning Transfer System Inventory. Human Resource Development Quarterly, 11(4), 333-360.

Hua, N. K., Ahmad, R. \& Ismail, A. (2011). The Impact of the Supervisor's Role in Training Programmes on the Transfer of Training: A Case Study in Four East Malaysian Local Governments. Research and Practice in Human Resource Management, 19(2), 24-42.

Hussain, R. M. (2011). An Empirical Study of the Relationship Between Motivation to Transfer and Transfer of Training. Far East Journal of Psychology and Business, $5(4), 47-56$.

Ismail, A. Bin, Sieng, L. L. C., Abdullah, M. M. Bin, \& Francis, S. K. (2010). Linking Supervisor's Role in Training Programs to Motivation to learn as an Antecedent of Job Performance. Intangible Capital, 6(1), 1-25.

Jehanzeb, K., \& Bashir, N. A. (2013). Training and Development Program and Its Benefits to Employee and Organization: A Conceptual Study. European Journal of Business and Management, 5(2), 243-252.

Joo, Y. J., Lim, K. Y., \& Park, S. Y. (2011). Investigating the Structural Relationships Among Organisational Support, Learning Flow, Learners' Satisfaction and Learning Transfer in Corporate E-Learning. British Journal of Educational Technology, 42(6), 973-984.

Kasim, R. S. R., \& Ali, S. (2011). The Influence of Training Design on Training Transfer Performance Among Support Staff of Higher Education Institution in Malaysia. International Journal of Innovation, Management and Technology, 2(5), 377.

Kia, N., \& Ismail, I. B. (2013). The Relationship Between Environmental Characteristics and Training Transfer. International Journal of Business and Social Science, 4(12), 196-203.

Kossek, E. E., Pichler, S., Bodner, T., \& Hammer, L. B. (2011). Workplace Social Support and Work-Family Conflict: A Meta- Analysis Clarifying the Influence of General and Work-Family- Specific Supervisor and Organizational Support. Personnel Psychology, 64(2), 289-313.

Lim, D.H., \& Johnson, S. D. (2002). Trainee Perceptions of Factors That Influence Learning Transfer. International Journal of Training and Development, 6(1), 36-48. Locke, E. A., \& Latham, G. P. (1990). A Theory of Goal Setting \& Task Performance. Prentice-Hall, Inc.

Manju, S., \& Suresh, B. H. (2011). Work Environment Factors and Implications for Transfer of Training. SDMIMD Journal of Management, $2(1)$, 32-41.

Maung, K. M. and Chemsripong, S. (2014). Does Supervisor Support Create Effective Transfer of Transfer of Training and Firm' Performance? Case of Myanmar Private Manufacturing Firms. Asia Business and Economics Journal, 16-28.

Ng, K. H. (2015). Supervisory Practices and Training Transfer: Lessons from Malaysia. Asia Pacific Journal of Human Resources, 53(2), 221-240.

Nijman, D. J. J., Nijhof, W. J., Wognum, A. A. M., \& Veldkamp, B. P. (2006). Exploring Differential Effects of Supervisor Support on Transfer of Training. Journal of European industrial training, 30(7), 529-549.

Nijman, D. J., \& Gelissen, J. (2011). Direct and Indirect Effects of Supervisor Support on Transfer of Training. In Supporting Workplace Learning. Springer Netherlands, 5(Professional Practice based Learning), 89-106.

Nilsen, P. (2015). Making Sense of Implementation Theories, Models and Frameworks. Implementation Science, 10(53), 1-13.

Noe, R. A., \& Schmitt, N. (1986). The Influence of Trainee Attitudes on Training Effectiveness: Test of a Model. Personnel Psychology, 39(3), 497-523.

Noe, R.A. (2013). Employee Training And Development (6th Ed.). Illinois: McGraw Hill Irwin.

Ömer, A. V. C. I. (2016). Goal Setting Theory: What It Implies for Strategic Human Resource Development. Maliye Araştırmaları Dergisi, 1(3), 39-46.

Park, J., \& Wentling, T. (2007). Factors Associated With Transfer of Training In Workplace E-Learning. Journal of Workplace Learning, 19(5), 311-329.

Reio, T. G., Nimon, K., \& Shuck, B. (2015). Preface Quantitative Data-Analytic Techniques to Advance HRD Theory and Practice. Advances in Developing Human Resources, 17(1), 3-11.

Sari, R. N., \& Basri, Y. M. (2015). The Moderating Effect of Goal Setting on Performance Measurement System-managerial Performance Relationship. Procedia Economics and Finance, 31, 876-884.

Sekaran, U., \& Bougie, R. (2011). Research Methods for Business: A Skill Building Approach. John Wiley \& Sons.

Shi, J., \& Liu, X. (2015). Empirical Study of Factors Affecting Training Transfer of Grassroots Employees in Petroleum Enterprises. Open Petroleum Engineering Journal, 8, 368-372.

Tajudin, A., Noor, N. M., \& Mustapha, R. M. R. (2014). The Role of Design Factors in Influencing Training Transfer among Small Businesswomen. International Journal of Management Excellence, 3(2), 432-435.

Van der Klink, M. R., Gielen, E. W. M. and Nauta, C. (2001). Supervisory Support as a Major Condition to Enhance Transfer. International Journal of Training and Development, 5(1), 52-63.

Van der Locht, M., van Dam, K., \& Chiaburu, D. S. (2013). Getting the Most of Management Training: The Role of Identical Elements for Training Transfer. Personnel Review, 42(4), 422-439.

Velada, R., \& Caetano, A. (2007). Training transfer: The Mediating Role of Perception of Learning. Journal of European Industrial Training, 31(4), 283-296.

Wen, M. L. Y., \& Lin, D. Y. C. (2014). Trainees' Characteristics in Training Transfer: The Relationship Among Self-Efficacy, Motivation to Learn, Motivation to Transfer and Training Transfer. International Journal of Human Resource Studies, 4(1), 114-129.

Werner, J., \& DeSimone, R. (2011). Human Resource Development: Cengage Learning.

Wexley, K. N. \& Latham, G. P. (2002). Developing and Training Human Resources in Organizations. Upper Saddle River: Prentice Hall.

Yamnill, S., \& McLean, G. N. (2001). Theories Supporting Transfer of Training. Human Resource Development Quarterly, 12(2), $195-208$.

Zahari, I. B., \& Obaid, T. F. (2014). The Role of Key Factors of Training Transfer on Employee's Job Performance: A Review. European Scientific Journal, 2, 163-169.

Zumrah, A. R. (2014). Service Quality in Malaysian Public Sector: The Role of Transfer of Training. Procedia-Social and Behavioral Sciences, $144,111-117$.

Zumrah, A. R., \& Boyle, S. (2015). The Effects of Perceived Organizational Support and Job Satisfaction on Transfer Of Training. Personnel Review, 44(2), 236-254. 